\title{
FAKTOR - FAKTOR YANG BERPENGARUH TERHADAP TERJADINYA KANDIDIASIS ERITEMATOSA PADA PENGGUNA GIGITIRUAN LENGKAP
}

\author{
Zulfikar Gaib \\ Program Studi Kedokteran Gigi \\ Universitas Sam Ratulangi
}

\begin{abstract}
Abstrak
Kehilangangigi pada seseorang dapat mengakibatkan terjadinya perubahananatomis, fisiologis maupunfungsional, bahkantidak jarang pulamenyebabkantraumapsikologis. Kehilangan gigi yang terjadidapat ditanggulangi dengan pembuatan restorasi berupa gigitiruan lepasan dan gigitiruan cekat.

Pemakaian gigitiruan seringkali dapat menimbulkan masalah yang lain apabila tidak diperhatikan kebersihan dan perawatan. Halini dapat dapat mengakibatkan terjadinya penumpukan sisa makanan yang merupakan predisposisi terbentuknya plak, sehingga meningkat prevalensi mikroorganisme Kandida albikan dan menyebabkan terjadinya kandidiasis. Terjadinya kandidiasis pada rongga mulut diawali dengan adanya kemampuan perlekatan kandida pada mukosa mulut sehingga mengakibatkan proliferasi, kolonisasi tanpa gejala atau disertai dengan gejala infeksi.

Kandidiasis di rongga mulut dapat dibedakan atas Kandidiasis Pseudomembrane (oral trush), Kandidiasis Anglular Cheilitis, Kandidiasis Hiperplastik Kronik, dan Kandidiasis eritematosa. Pada pasien pengguna gigitiruan, kandidiasis yang paling banyak ditemukan yakni Kandidiasis eritematosa.
\end{abstract}

Kata kunci : Gigitiruan lengkap, kandida albikan, kandidiasis eritematosa 


\section{PENDAHULUAN}

Kehilangangigi pada seseorang dapat mengakibatkan terjadinya perubahananatomis, fisiologis maupunfungsional, bahkantidak jarang pulamenyebabkantraumapsikologis. Penyebab kehilangan gigi bisa bermacam-macam, namun yang paling umum diakibatkan oleh penyakit karies danpenyakit periodontal. Kehilangan gigi yang terjadidapat ditanggulangi dengan pembuatan restorasi berupa gigitiruan lepasan maupun gigitiruan cekat. Gigitiruan lepasan dimaksud bisa berupa gigitiruan sebagian lepasan untukmenanggulangi kehilangan sebagian gigi dan gigitiruan lepasan penuh untukmenanggulangi kehilangan seluruh gigi. ${ }^{1}$

Solusi pemakaian gigitiruan seringkali dapat menimbulkan masalah yang lain apabila tidak diperhatikan kebersihan dan perawatannya. Pada pasien pengguna gigitiruan yang tidak memerhatikan kebersihan mulut termasuk gigitiruannya sesuai instruksi yang diberikan dokter gigi, dapat mengakibatkan terjadinya penumpukan sisa makanan yang merupakan predisposisi terbentuknya plak. Hal ini terutama terjadi pada pasien lanjut usia.Seiring dengan meningkatnya usia terjadi perubahan dan kemunduran fungsi kelenjar saliva, dimana kelenjar parenkim hilang yang digantikan oleh jaringan lemak, lining sel duktus intermediate mengalami atropi yang mengakibatkan pengurangan jumlah aliran saliva.Selain itu, penyakitpenyakit sistemis yang diderita pada usia lanjut dan obat-obatan yang digunakan untuk perawatan penyakit sistemis.Keadaan ini yang mengakibatkan meningkatnya prevalensi mikroorganisme Kandida albikan dalam mulut pasien., ${ }^{2,3}$

Kandida albikan merupakan salah satu flora normal di rongga mulut. Penelitian yang dilakukan oleh Campos dkk. menemukan Kandida albikan sebagai spesies jamur utama yang ditemukan pada pemakai gigitiruan. Penelitian lainnya yang dilakukan oleh Zomorodian dkk pada 114 subjek penelitian menemukan adanya Kandida albikan sebanyak 41,5\%, Kandida glabrata $18,4 \%$ dan Kandida tropikalis $12,9 \%$. Peningkatan jumlahKandida albikanyang terjadi dipengaruhi oleh beberapa faktor, terutama penggunaan gigitiruan, serostomia, penyakit sistemik, penyakit autoimun, trauma, kondisi ph dalam rongga mulut. ${ }^{3}$

Kandidiasis di rongga mulut dapat dibedakan atas Kandidiasis Pseudomembran (oral trush), Kandidiasis Angular Cheilitis, Kandidiasis Hiperplastik Kronik, dan Kandidiasis Eritematosa. Secara klinis Kandidiasis Eritematosa dapat dibedakan menjadi tiga tipe yaitu inflamasi ringan yang terlokalisir, Erythema lebih tersebar meliputi sebagian atau seluruh mukosa yang tertutup gigitiruan dan inflamasi papilla hiperplasia. ${ }^{5}$ 
Pada pasien pengguna gigitiruan, kandidiasis yang paling banyak ditemukan yakni Kandidiasis eritematosa. Penelitian yang dilakukan pada 24 pasien yang menggunakan gigitiruan terus menerus, prevalensinya 53,85\%, sedangkan pada pasien yang membuka gigitiruan pada malam hari prevalensinya $36,36 \%$. (Afrina,L,2007) ${ }^{4,5}$

Terjadinya Kandidiasis pada rongga mulut diawali dengan adanya kemampuan kandida untuk melekat pada mukosa mulut, dimana hal ini yang menyebabkan terjadinya infeksi. Perlekatan jamur pada mukosa mulut mengakibatkan proliferasi, kolonisasi tanpa gejala atau disertai dengan gejala infeksi. Kandidiasis eritematosa pada pengguna gigitiruan terjadi karena adanya invasi jamur kandida ke dalam jaringan dan penggunaan gigitiruan tersebut menyebabkan akan bertambahnya mukus dan serum, namun pelikel saliva berkurang.

Berdasarkan uraian di atas penulis terdorong untuk perlu mengetahui lebih jauh faktor faktor yang memengaruhi terjadinya Kandidiasis Eritematosa pada pasien pengguna gigitiruan.

\section{TINJAUAN PUSTAKA}

\section{Kandida Albikan}

Kandida merupakan mikroflora normal dalam rongga mulut, dimana mikroorganisme ini jumlahnya mencapai 40 - $60 \%$ dari populasi (Silverman S, 2001). Jamur ini dapat menjadi patogen dalam kondisi tertentu atau pada orang - orang yang mengalami penurunan sistem imun tubuh. ${ }^{6,7}$ Spesies kandida dalam rongga mulut bermacam-macam, yakni:Kandida albikan, Candida parapsilosis, Candida tropicalis, Candida glabrata, danCandida guillermondii.Kandida albikanmerupakan organisme komensal dan merupakan bagian dari flora mulut, serta mampu menghasilkan infeksi-infeksi oportunis dalam rongga mulut jika ada faktor-faktor predisposisi yang mendukung.

Kandidaalbikanmerupakan jamur dimorfik karena mempunyai kemampuan untuk tumbuh dalam dua bentuk yang berbeda, yaitu sebagai sel tunas yang akan berkembang menjadi blastospora dan menghasilkan kecambah yang akan membentuk hifa semu, baik dalam tubuh maupun dalam biakan. Perbedaan bentuk ini tergantung pada faktor eksternal yang mempengaruhinya. Jamur kandida dengan ukuran 3-5 x 5-10/ $\mu$ m inidapat tumbuh pada variasi $\mathrm{pH}$ yang luas, tetapi pertumbuhannya akan lebih baik pada $\mathrm{pH}$ antara 4,5-6,5. Jamur ini dapat tumbuh dalam pembenihan dengan suhu $28^{\circ} \mathrm{C}-37^{\circ} \mathrm{C}$. Kandida albikan membutuhkan 
senyawa organik sebagai sumber karbon dan sumber energi untuk pertumbuhan dan proses metabolismenya. Jamur ini merupakan organisme anaerob fakultatif. ${ }^{8-11}$

\section{Kandidiasis rongga mulut}

Kandidiasis rongga mulut merupakan salah satu penyakit infeksi yang disebabkan oleh jamur dalam rongga mulut, terutama oleh Kandida albikan.

Kandida albikan merupakan jamur yang pada keadaan normal merupakan kelompok organisme komensal yang berada dalam rongga mulut. Ketika seseorang mengalami gangguan imun, jamur ini akan bersifat patogen. Bila terjadi infeksi, filamen dari jamur ini akan berkembang dan meluas ke daerah apikal, dimana bentuk cabang lateral mulai terlihat pada hifa dan mycelium, dan devisi sel tunggal yang dihubungkan dengan bentuk yeast. Adhesi kandida pada dinding sel epitelial yang merupakan langkah penting pada infeksi awal ditingkatkan oleh komponen dinding sel jamur seperti mannose, reseptor $\mathrm{Cd} 3$, manoprotein, dan sakarin. Proses ini akan diperberat dengan faktor-faktor predisposisinya dan terus berlanjut sehubungan dengan imunodefisiensi yang dialami oleh pasien Kandidiasis pada mukosa mulut dapat memberikan pola gambaran klinis yang beragam. Banyak pasien memberikan gambaran pola tunggal, namun beberapa pasien lainnya akan memberikan gambaran pola Kandidiasis lebih dari satu pola klinis. ${ }^{9,11,12,14}$ Kandidiasis di rongga mulut dapat dibedakan atas Kandidiasis Pseudomembrane (oral trush), Kandidiasis Anglular Cheilitis, Kandidiasis Hiperplastik Kronik, dan Kandidiasis eritematosa. Pada pasien pengguna gigitiruan, kandidiasis yang paling banyak ditemukan yakni Kandidiasis eritematosa.

Kandidiasis Eritematosa juga dikenal dengan nama kandidiasis atropik akut atau dentures sore mouth atau dentures stomatitis. Kira-kira $26 \%$ pemakai gigi tiruan mempunyai keluhan ini. Gigitiruan bukan merupakan satu-satunya penyebab terjadinya perubahan pada mukosa mulut. Budtz-Jorgensen dalam tulisannya mengemukakan bahwa Kandidiasis eritematosa dapat disebabkan oleh bermacam-macam faktor yaitu trauma, infeksi, pemakaian gigitiruan yang terus menerus, oral hygiene jelek, alergi, dan gangguan sistemik. ${ }^{20,21}$

Adanya biofilm atau plak pada gigitiruan yang berkontak dengan permukaan mukosa adalah faktor etiologi yang terbesar dalam patogenesis yang terjadi pada Kandidiasis ini. Kolonisasi mikroba yang ada pada permukaan gigitiruan membentuk suatu deposit yang 
dikenal sebagai plak denture. Porositi pada permukaan gigi tiruan berperan penting dalam proses pembentukan plak. Plak pada basis gigi tiruan merupakan tempat yang baik bagi berkumpulnya mikroorganisme termasuk Kandida albikan.Peningkatan jumlah Kandida albikan dapat mengubah sifat komensal menjadi parasit, yaitu dari bentuk yeast menjadi hyphae. Bentuk hyphae ini merupakan inisiator invasi kedalam jaringan sehingga dapat menimbulkan Kandidiasis eritematosa.. ${ }^{21}$

Berlainan dengan bentuk Kandidiasis pseudomembran penderita Kandidiasis eritematosa tidak ditemui adanya plak-plak putih. Tampilan klinis yang terlihat pada Kandidiasis ini yaitu daerah yang eritema atau kemerahan dengan adanya sedikit perdarahan di daerah sekitar dasar lesi. Hal ini sering dikaitkan dengan terjadinya keluhan mulut kering pada pasien. Lesi ini dapat terjadi dimana saja dalam rongga mulut, tetapi daerah yang paling sering terkena adalah lidah, mukosa bukal, dan palatum. ${ }^{14-17}$ Kandidiasis eritematosa dapat diklasifikasikan dalam 3 tipe (tipe Newton), yaitu $^{19}$ :

Tipe 1 : inflamasi sederhana terlokalisir atau pinpoint hyperemia.(Gambar 1)

Tipe 2 : eritematosa atau tipe sederhana yang umum erythema lebih tersebar meliputi sebagian atau seluruh mukosa yang tertutup gigi tiruan.(Gambar 2)

Tipe 3 : tipe granular (inflamasi papilla hyperplasia) umumnya meliputi bagian tengah palatum durum dan alveolar ridge.(Gambar 3)

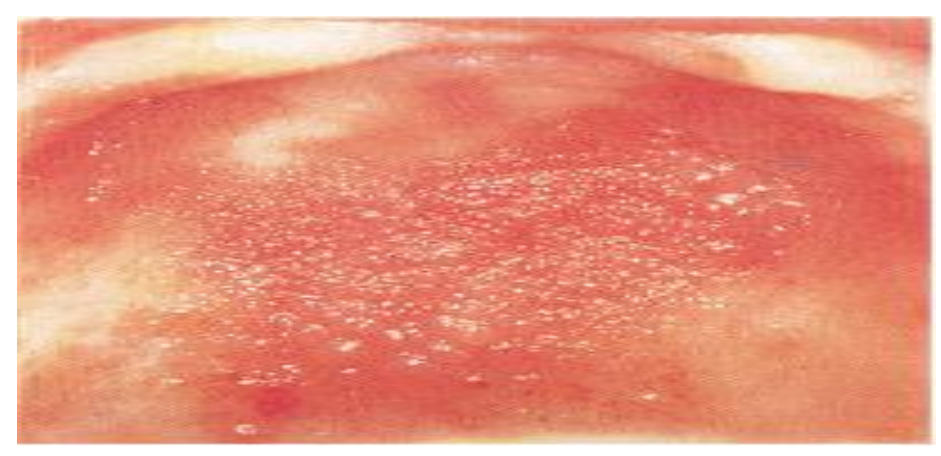

Gambar 1. Kandidiasis eritematosa tipe 1 


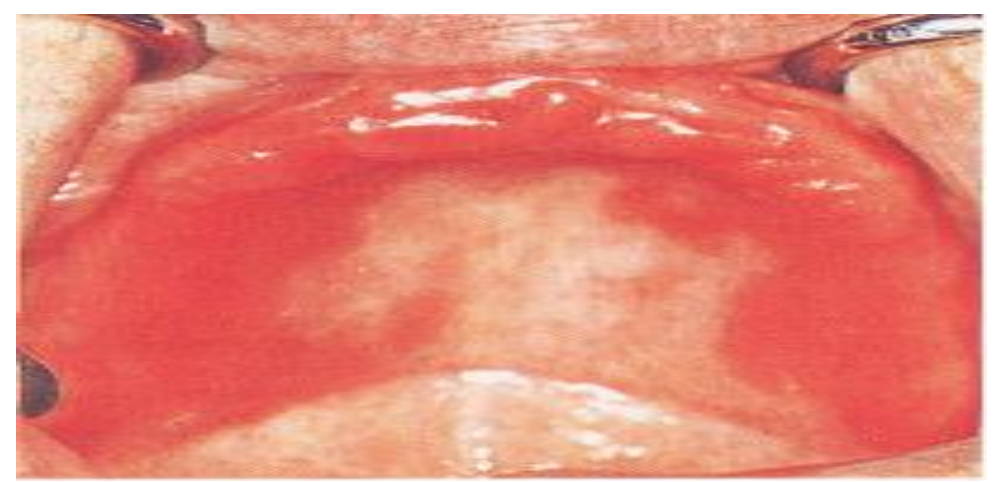

Gambar 2. Kandidiasis eritematosa tipe 2

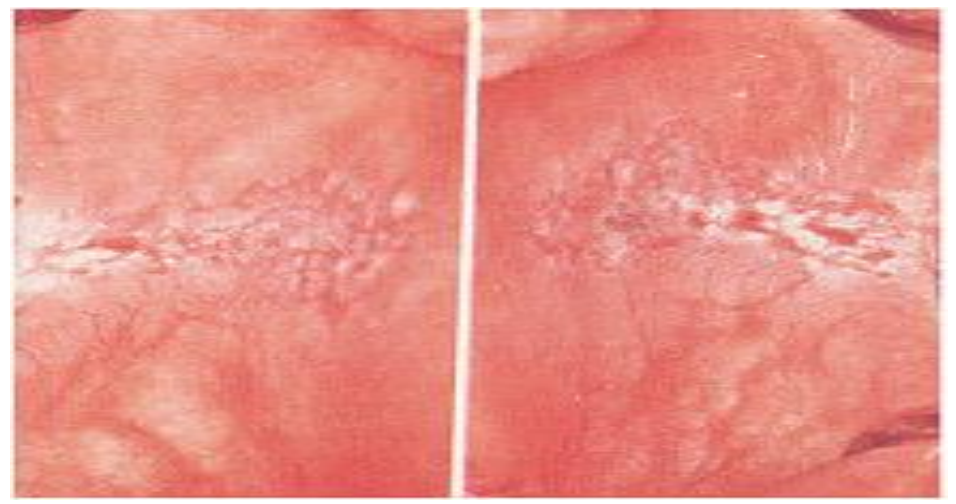

Gambar 3. Kandidiasis eritematosa tipe 3

\section{Gigi Tiruan Lengkap}

Gigitiruan adalah suatu alat tiruan yang di gunakan untuk menggantikan sebagian atau seluruh gigi asli yang sudah hilang serta mengembalikan perubahan-perubahan struktur jaringan yang terjadi akibat hilangnya gigi asli.Tujuan pembuatan gigitiruan, baik itu gigitiruan lengkap maupun gigitiruan sebagian pada hakekatnya adalah untuk memperbaiki fungsi pengunyahan, pengecapan, estetis, menjaga kesehatan jaringan serta mencegah kerusakan lebih lanjut dari struktur organ rongga mulut. Pada pasien lanjut usia itu sendiri tujuannya adalah untuk memelihara kesehatan dan fungsi sistem pengunyahan dengan menetapkan ukuran pencegahan tanpa melibatkan pengobatan yang berlebihan.

Basis gigitiruan lepasan dapat dibuat dari logam atau campuran logam, kebanyakan basis gigitiruan dibuat menggunakan polimer. Resin akrilik lebih sering digunakan karena keuntungan bahan resin akrilik ringan, murah, warna sama dengan warna gingival, mudah pembuatannya dan mudah dilakukan preparasi. Akrilik adalah suatu bahan yang masih 
digunakan untuk pembuatan gigitiruan..Resin ini mempunyai kekuatan, warna yang sesuai dengan warna jaringan mulut yang digantikan. Sifat resin ini adalah bentuk stabil, tidak mengiritasi, tidak toksik, mudah dimanipulasi. Kerugiannya, akrilik mempunyai pori-pori mikro sehingga memudahkan sisa makanan dan bakteri masuk ke dalamnya. ${ }^{22}$ Terdapat 4 jenis resin akrilik $:^{22}$

1. Resin akrilik heat cured

2. Resin akrilik cold cured

3. Resin akrilik microwave cured

4. Resin akrilik visible light cured

Dari hasil penelitian yang dilakukan tentang hubungan lama pemakaian gigi tiruan dengan banyaknya jumlah koloni Kandida albikandiperoleh bahwa semakin lama pengunaan gigi tiruan maka semakin banyak pula jumlah koloni Kandida albikan.Bagi penderita yang menggunakan gigitiruan sebaiknya diberi penjelasan yang lebih terperinci mengenai pemeliharaan gigitiruan, cara pemakaian gigitiruan dan akibat-akibat yang timbul apabila hal tersebut kurang diperhatikan. ${ }^{22}$

Semula adhesi Kandida tergantung pada mieschondrotinase dan neuraminidase, yang mampu menurunkan kondisi epitel mulut .kolonisasi kandida yang terbentuk di dekat mukosa mulut menentukan peningkatan eksudat inflamasi.perkembangan kandida, keadaan ini lebih banyak terjadi pada permukaan gigitiruan yang berkontak dengan mukosa.gigitiruan berpotensi meningkatkan zat bakteri yang menyebabkan rusaknya imunoglobulins pada air liur.sistem imun merespon terjadinya deposit plak dengan terbentuknya lesi.Reaksi hipersensivitas yang terjadi pada kandida albican menyebabkan terjadinya inflamasi.Porositas dalam jumlah besar dapat melemahkan gigi tiruan sehingga mudah patah dan makanan mudah menempel sehingga gigitiruan cepat berbau Perlekatan mikroorganisme pada gigitiruan dipengaruhi oleh kekasaran permukaan dan porusitas bahan gigitiruan sehingga mikroorganisme dapat berpenetrasi ke dalamnya.

Pemakaian gigitiruan lepas yang kurang baik akan menyebabkan iritasi setempat yang terus-menerus pada selaput lendir. Penurunan volume saliva dapat mengakibatkan perubahan pada mukosa mulut dan merupakan predisposisi invasi jamur Kandida.Kandidiasis eritematosadapat terjadi akibat jumlah Kandida Albikanyang 
meningkat.Kandida Albikan yang berperan pada infeksi ini biasanya terdapat pada permukaan palatal pemakai gigitiruan.Pengelupasan sel epitel sehingga terjadinya atrofi epitel merupakan gambaran khas dari eritematosa ${ }^{28,22}$

\section{PEMBAHASAN}

Pada umumnya pasien yang menggunakan gigitiruan selalu mengeluhkan kesakitan serta bau yang tidak enak. Hal ini terjadi karena adanya invasi mikrobial pada gigitiruan salah satunya oleh karena jamur Kandida. Penyakit yang ditimbulkan oleh jamur Kandida antara lain Kandidiasis Eritematosa. Faktor-faktor predisposisi terhadap terjadinya Kandidiasis Eritematosa terbagi atas dua yaitu faktor sistemik dan faktor lokal.Faktor sistemik yang dianggap merupakan faktor predisposisi terbesar bagi terjadinya Kandidiasis Eritematosa yakni pasien dengan kondisi penyakit sistemik Diabetes Melitus serta HIV AIDS. Adapun faktor lokal yaitu plat gigi tiruan akrilik sebagai tempat berkembangnya kandida albikan, kondisi ph rongga mulut, dan trauma.

\section{Diabetes melitus}

Diabetes mellitus, suatu penyakit kronik yang ditandai dengan kekurangan insulin baik relatifmaupun absolutyang mengakibatkan metabolisme karbohidrat, lemak, dan protein terganggu. Diabetes mellitusmerupakan salah satu penyakit yang paling banyak dan paling sering dijumpai pada manusia, dimana sebagian dari penderita tersebut tidak sadar maupun tidak terdiagnosa bahwa telah menderita penyakit tersebut hingga muncul gejalagejala yang lebih spesifik.. Keadaan tersebut dapat menyebabkan terjadinya disfungsi aliran saliva karena adanya kehilangan cairan dari tubuh dalam jumlah yang banyak, sehingga aliran saliva juga berkurang. Selain itu, juga menyebabkan komplikasi berupa microangiopathy dan xerostomiayang paling sering muncul pada penderita diabetes mellitusterkontrol atau tidak terkontrol.Xerostomiaumumnya berhubungan dengan berkurangnya aliran saliva, dapat terjadi akut atau kronis, bersifat sementara atau menetap dan ada saliva yang hanya berkurang sedikit atau hampir seluruhnya.Xerostomia merupakan temuan klinis yang sering ditemukan dalam praktek sehari-hari pada pasien kehilangan gigi, tetapi jarang terdeteksi oleh praktisi dokter gigi sehingga nantinya setelah pemakaian gigitiruan penuh (GTP) akan menimbulkan permasalahan pada pasien. 
Pada penderita xerostomia, saliva menjadi sangat berkurang sehingga akan mengurangi retensi yang berakibat pada kurangnya stabilisasi dan proteksi mekanis gigitiruan dukungan jaringan oleh selapis tipis saliva.Berkurangnya saliva menyebabkan mengeringnya selaput lendir, mukosa mulut menjadi kering, mudah mengalami iritasi dan infeksi. Keadaan ini disebabkan oleh karena tidak adanya daya lubrikasi infeksi dan proteksi dari saliva.Kekeringan pada mulut menyebabkan fungsi pembersih dari saliva berkurang, sehingga terjadi radang yang kronis dari selaput lendir yang disertai keluhan mulut terasa seperti terbakar pada mukosa mulut atau lidah.Lidah menjadi kering, merah seperti daging sapi, berfisur dan atropi, terutama pada xerostomia yang parah.Mukosa yang kering menyebabkan pemakaian gigitiruan tidak menyenangkan, karena gagal untuk membentuk selapis tipis mukus untuk tempat gigitiruan melayang pada permukaannya.

Selain itu karena turunnya tegangan permukaan antara mukosa yang kering dengan permukaan girgitiruan. Susunan mikroflora mulut mengalami perubahan, dimana mikro organisme kariogenik seperti Kandida meningkat. Selain.itu, fungsi bakteriostase dari saliva berkurang. Akibatnya pasien yang menderita xerostomia akan mengalami peningkatan proses infeksi Kandida.Kehilangan cairanSaliva dari penderita diabetes mendukung pertumbuhan dari Kandida albican in vitro dan telah ditunjukkan pada permukaan gigitiruan dari penderita diabetes.Pada permukaan gigitiruan penderita diabetes terdapat lebih banyak peningkatan jumlah koloni yeast bila dibandingkan dengan pengguna gigitiruan yang tidak menderita diabetes. ${ }^{27,29,30}$

\section{Acquired Immuno Deficiency Syndrome}

AIDS adalah penyakit yang di sebabkan oleh virus HIV yang menyerang sistem kekebalan tubuh. Hal ini di tandai dengan penurunan CD4+ limfosit dalam darah. CD4+ limfosit $\mathrm{T}$ di gunakan untuk menilai kemampuan individu yang terinfeksi untuk bertahan terhadap infeksi oportunistik, CD4+ normal adalah $700 \mathrm{sel} / \mathrm{mm}^{3}$, penurunan kekebalan pada pasien HIV adalah $500 \mathrm{sel} / \mathrm{mm}^{3}$ sedangkan pada pasien yang cukup parah penurunan mencapai $200 \mathrm{sel} / \mathrm{mm}^{3}$. Limfosit CD4+ kurang dari $200 \mathrm{sel} / \mathrm{mm}^{3}$ merupakan faktor resiko terjadinya kandidiasis. Pada pasien penderita AIDS fungsi sel $\mathrm{T}$ yang terganggu karena intervensi virus HIV melalui kulit dan mukosa yang dimungkinkan karena peran lektin yang spesifik pada sel dendrite, DC-SIGN sehingga mampu berikatan dengan virus HIV meskipun tidak mampu mengantarkan masuk ke dalam sel, tetapi 
memudahkan transport HIV oleh dendrite ke organ limfoid dan menambah jumlah limfosit $\mathrm{T}$ yang terinfeksi. Munculnya lesi pada mukosa akibat intervensi HIV yang diperantarai peran lektin dan DC-SIGN yang mengakibatkan infeksi jamur pada mukosa mulut, mengawali munculnya infeksi sekunder pada mulut penderita .Penelitian pada tahun 2007 di Surabaya pada pasien HIV didapati gambaran klinis terjadi infeksi pada kelenjar saliva yang menyebabkan kelenjar parotis mengalami pembesaran unilateral atau bilateral. Keadaan ini membuat aliran saliva berkurang sehingga menyebabkan pertumbuhan jamur Kandida Albikan meningkat. ${ }^{31}$

\section{Penumpukan Plak Pada Basis Gigitiruan Akrilik}

Basis akrilik gigitiruan lepasan yang berkontak langsung dengan saliva, mengabsorbsi molekul saliva tertentu, dan membentuk lapisan organik tipis yang disebut acquired pellicle. Pelikel mengandung protein yang mengikat perlekatan mikroorganisme rongga mulut,sehingga mikroorganisme melekat pada permukaan gigitiruan dan berkembang biak serta berkoloni dengan mikroorganisme lain membentuk plak gigi tiruan. Plak gigi tiruan merupakan penyebab masalah yang berhubungan dengan jaringan mulut,rasa tidak enak, stomatitis angularis, bau mulut, perubahan warna pada gigitiruan dan peradangan jaringan mukosa di bawah gigitiruan yang disebut eritematosa. Proses terbentuknya plak pada gigitiruan sama dengan proses yang terjadi pada gigi asli. Tabel di bawah ini menunjukan perlekatan kandida pada permukaan masing masing gigitiruan. ${ }^{22,23}$

\begin{tabular}{|l|c|}
\hline a. Heat cured & $114,10 \pm 18,30$ \\
\hline b. Cold cured & $132,50 \pm 20,53$ \\
\hline c. Microwave cured & $121,60 \pm 30,63$ \\
\hline d. Visible light cured & $191,50 \pm 45,13$ \\
\hline
\end{tabular}

Rata-rata jumlah Kandida Albikan pada permukaan resin akrilik (mm2) ${ }^{22}$

Gambaran pada tabel tersebut memperlihatkan bahwa permukaan plat resin akrilik heat cured paling sedikit dilekati oleh sel Kandida albikan hal ini di sebabkan heat cured paling kecil tingkat porositasnya dibandingkan dengan jenis-jenis resin akrilik yang lain. Pada pemeriksaan mikroskopis terlihat bahwa sel Kandida albikan banyak bergerombol 
pada bagian porusitas resin akrilik heat cured dan microwave cured. Sel Kandida albikan tampak dalam bentuk budding dengan warna ungu, sedangkan pada permukaan pelat resin akrilik cold cured dan visible light cured sel Kandida albikantampak menyebar merata menutupi permukaan porusitas permukaan plat. Daya lekat Kandida Albikanpada gigitiruan lebih besar daripada Kandida jenis lainya,karena tegangan permukaan Kandida albikan lebih besar dari pada jenisKandida yang lain. ${ }^{22}$

\section{Kondisi ph rongga mulut}

Rendahnya tingkat $\mathrm{pH}$ pada rongga mulut dapat mendukung adhesi dan proliferasi yeast Kandida.Pada kondisi pH 3 tidak hanya bagus untuk adhesi yeast tetapi juga untuk enzimatik dan proteinase yang bersama sama dengan enzim lipase merupakan faktor yang paling penting dari virulensi kandida karena efek sitotosik dan sitolitik. Karbohidrat yang terdapat di dalam air liur dapat menjadi sumber makanan tambahan bagi yeast kandida. Hasil metabolisme gula yang menghasilkan asam berkontribusi membuat $\mathrm{pH}$ menjadi rendah, sehingga mendukung pertumbuhan Kandida albikan di dalam rongga mulut. ${ }^{28}$

\section{Trauma akibat pemakaian gigitiruan akrilik}

Trauma karena gigitiruan yang tidak stabil juga merupakan salah satu faktor etiologi hal ini karena terjadinya peradangan jaringan lunak dibawah gigitiruan yang menyebabkan terjadinya eritematosa, analisis secara imunohistokimia pada jaringan mukosa yang terdapat eritematosa telah menunjukan kemungkinan trauma pada variasi ekspresi antigen membran basal. Trauma juga menentukan hubungan Kandidiasis eritematosa dengan pemakaian gigitiruan.Cawson menunjukkan apabila trauma dan infeksi kandida terjadi bersamaan, kondisi ini menyebabkanterjadinya patogenesis dari Kandidiasiseritematosa. Dalam beberapa hal trauma dapat bertindak sebagai co-faktor yang berpihak pada adhesi dan penetrasi yeast,sokongan phlogosis menopang palatum dan meningkatkan permeabilitas epitelium untuk racun dan agen-agen yang dihasilkan oleh jamur kandida. $^{28}$ 


\section{KESIMPULAN}

Dari hasil pemabahasan yang telah dilakukan dapat di tarik kesimpulan sebagai berikut

: Pertumbuhan Kandida eritematosa pada pasien pengguna gigitiruan penuh sangat di pengaruhi oleh faktor sistemik dan penyakit autoimun seperti: Diabetes Mellitus, AIDS, Xerostomia dan faktor lokal seperti, plat gigitiruan sebagai tempat berkembangnya kandida albikan, kondisi ph dalam rongga mulut.

Diharapkan hasil skripsi ini dapat bermanfaat bagi intitusi kedokteran gigi,masyarakat, penulis sendiri dan masyarakat umum yang menggunakan gigitiruan dalam menjaga kebersihan,kebiasaan pemakaian dan lama pemakaian gigitiruan untuk mencegah pertumbuhan Kandida albikan yang berlebihan sebagai penyebab terjadinya Kandida Eritematosa.

\section{DAFTAR PUSTAKA}

1. Badan penelitian dan Pengembangan Kesehatan Departemen Kesehatan,Republik Indonesia 2008; p.132

2. Felton D,Lyndon cooper,Ibrahim Duqum,etall.Evidence-based guedelines for the care and maintenance of complete denture : a publication of the american college of prosthondontists.2011;142;1s-20s

3. Zomorodian K,Haqhiqhi NN,Pakshir K.,assessment of candida species colonization and denture-related stomatitis in complete denture weares. [serial online] med mycol 2011 feb,49(2):206-11.available from URL: http//www.ncbi.nlm.nih.gov/pubmed/20795762

4. Afrina L,Prevalensi Denture Stomatitis Yang Disebabkan Kandida Albikan pada Pasien Gigitiruan Rahang Atas Di Klinik FKG USU;2007.

5. Dahar E. Penatalaksanaan gigi tiruan penuh rahang bawah dengan reservoir (mandibular split denture) pada pasien xerostomia.

6. Simatupang MM. Candida Albicans. Medan. FK USU; 2009.

7. Springhouse. Professional Guide to Diseases. Oral thrush: introduction. $8^{\text {ed }}$. New York. Lippincott Williams \& Wilkins; 2005.

8. Panda. Dentures related stomatitis. [serial online] 2008 mar 19; [cited 2011.03.13]. Avalaible from: URL: http://pandatitit.blogspot.com/2008/05/denture-relatedstomatitis.html. 
9. Masdin. Kandidiasis mulut. [serial online] 2010 mar 16; [cited 2011.03.13]. Avalaible from: URL: http://www.pajjakadoi.co.tv/2010/03/candidiasis-mulut.html.

10. Samaranayake L. Essential microbiology for dentistry. Fungi of relevance to dentistry. $3^{\text {th }}$ ed. New York: Churcill Livingstone, Elsevier. 2006. p. 177-83.

11. Hendrawati DY. Candida Albicans. [serial online] 2008 aug. [cited 2011-01-28]; Available from: URL: http://mikrobia.files.wordpress.com/2008/05/yosephine-dianhendrawati-078114110.pdf.

12. Zunt LS. Oral candidiasis: Diagnosis and treatment. The J of Prac Hyg 2000

13. Flaischmann J, Silverman S, Epstein BJ. Oral fungal infection. In: Silverman S, Eversole LR, Truelove EL. Essential of oral medicine. London: BC Decker Inc; 2010.

14. Akpan A, Morgan R. Oral candidiasis. Postgrad Med J 2002; 78: 455-59.

15. Bruch JM, Treister MS. Clinical oral medicine and pathology. Oral infections. New York. Humana Press; 2010.

16. Farah CS, Lynch N, McCullough MJ. Oral fungal infections: an update for the general practitioner. Aus Dent J 2010; 55: 48-54.

17. Rossie K, Guggenheimer J. Oral candidiasis: Clinical manifestations, diagnosis, and treatment. University of Pittsburgh school of dental medicine and pathology. Pittsburgh, PA. 1997.

18. Bagg J, MacFarlane WT, Poxton RI, Smith JA. Essential microbiology for dental student. Oral fungal infection. United Kingdom. Oxford University Press. 2006. p.27480 .

19. Herawati E. Kandidiasis rongga mulut, gambaran klinis, dan terapinya. Bandung. FKG Unpad; 2008.

20. Junaedi E. Dentures stomatitis. [serial online] 2009 Mei 27; [cited 2011.02.08]. Avalaible from: URL: http://edjuna.blogspot.com/

21. USU. Streptococcus mutans pada gigi tiruan penuh. [serial online] 2008. [cited 2011-01-28]; Available from: URL: http://repository.usu.ac.id/bitstream/123456789/19050/4/Chapter\%20II.pdf

22. Tanjong A.pengaruh kosentrasi ekstrak kelopak bunga rosella (hibiscus sabdariffal)terhadap koloni candida albicans yang terdapat pada plat gigitiruan.Skripsi.Fkg Unhas.2011. 
23. Sunarintiyas S,Dyah I.Pengaruh cara pemrosesan resin akrilik terhadap sifat fisik dan mekanik.Gerbong inovasi desember 2005.

24. David,Elly M.perubahan warna lempeng resin akrilik yang di rendam larutan desinfektan sodium hipoklorit dan klorhexidin.Maj.Ked.Gigi. (Dent.J),Vol.38.no 1 Januari 2005:36-40

25. Husdiari M. Replika gigi. [serial online] 2008 Apr 14; [cited 2011.02.08]. Avalaible from: URL: http://mydentistarigigi.blogspot.com/

26. Roessler MD. Complete dentures successful for patients and dentists. Int Dent J 2003. 53, 340-45.

27. Salerno C,Michael poschale,etall. Candida-asociated denture stomatitis;

Med Oral Patol Oral Cir Bucal. 2011 Mar 1;16 (2):e139-43.

28. Coulthwaite L,J verren.Potensial pathogenic aspect of denture plaque;School Of biology, of oral\& health since,Manchester Metropolitan University.Manchester,UK .13 november 2007

29. Hopcroft MS,Tan C.Xerostomaia:an up date for clinicians;Australian dental journal.2010;55:238-244

30. Abu-elteen K.H, Hamad M.A,etall; prevalence of oral candida infection in diabetic patients;Bahrain medical bulletin,vol.28,no.1, march 2006

31. Patton LL, McKaig R, Strauss R, et al. Changing prevalence of oralmanifestations of human immunodeficiency virus in theera of protease inhibitor therapy. Oral Surg Oral Med OralPathol Oral Radiol Endod 2000;89:299-304 